TED J. CLUTTER

Executive Director

October 16,1998

Jeff Hahn

NREL

1617 Colorado Blvd.

Golden, CÖ 80401

Dear Jeff:

This letter and attachment constitutes the close out of Contract No. DE-FG-36$94 \mathrm{GO} 10023$ with tasks $3.1,3.2,3.3,3.4,3.5$ and 3.6 .

All of the required work for the above contract and tasks has been completed. An explanation of each task and a list of the deliverables for each appears below. The deliverables are numbered in the text and have been compiled in a separate attached section.

\title{
TASK 3.1
}

1994 Annual GRC Conference - This conference (annual meeting) was convened at the Little American Hotel in Salt Lake City, Utah, from October 2 - 5, 1994. Enclosed as deliverables are a copy of the preliminary announcement, a copy of the List of Exhibitors and Attendees, and a copy of the Final Program. These elements are numbered as attachments 3.1,1,2 and 3 respectfully.

\section{TASK 3.2}

Geothermal Well Control Drilling Course - This course was convened in Sacramento, California on.March 22 and 23, 1994. It was designed as a refresher course to the three concentrated courses convened in 1992. Included in the attachment packet is the course manual numbered 3.2,1 for this function. Because the course instructor was supplied by the UNOCAL Corporation, their logo appears on the cover of the course material.

\section{TASK 3.3}

GRC Library Expansion - The work in this task was performed. The start date of the contract was July 1, 1994. By December 31 of 1994, the number of citations was 14,292 and the key words entered to date were 5,814. By July 31, 1995, 17,120 citations had been entered and 10,721 sets of key words had been developed and entered. In addition to the above, the GRC Library was made available on the Internet, which essentially opened it up to the world. This was partially accomplished through the purchase and installation of a new database program. The following 


\section{DISCLAIMER}

This report was prepared as an account of work sponsored by an agency of the United States Government. Neither the United States Government nor any agency thereof, nor any of their employees, make any warranty, express or implied, or assumes any legal liability or responsibility for the accuracy, completeness, or usefulness of any information, apparatus, product, or process disclosed, or represents that its use would not infringe privately owned rights. Reference herein to any specific commercial product, process, or service by trade name, trademark, manufacturer, or otherwise does not necessarily constitute or imply its endorsement, recommendation, or favoring by the United States Government or any agency thereof. The views and opinions of authors expressed herein do not necessarily state or reflect those of the United States Government or any agency thereof. 


\section{DISCLAIMER}

Portions of this document may be illegible in electronic image products. Images are produced from the best available original document. 
documents are in support as attachments 3.3,1,2 and 3.

\section{TASK 3.4}

Geothermal Poster - The GRC, in collaboration with the Geothermal Education Office, designed the poster, had it sent out for review, had it printed, set up a disbursal mechanism and started the disbursal process. A poster has been included in the attachment section as 3.4,1.

\section{TASK 3.5}

1995 World Geothermal Congress - The WGC 1995 was convened in May of 1995 in Florence, Italy. The GRC sponsored an exhibit booth and sent four employees to this function. They were David N. Anderson, Executive Director; De Rasser, Staff Accountant; Estela Smith, Librarian and Joyce Mitchell, Publications Coordinator. Two documents have been placed in the attachments section: a List of Exhibitors and a List of Attendees. These documents are numbered as attachments $3.5,1$ and 2 .

\section{TASK 3.6}

Geothermal Heat Pump Training Center - The planning and architectural design for the Training Center was completed in 1994. A business plan was completed in November of 1995 along with a projection of income from course registration fees. Both of these documents have been included in the deliverables packet as attachments 3.6,1 and 2 .

Note: Because of a decision by the Geothermal Heat Pump Consortium in Washington, D.C. (who pass through DOE funds) to make the Training Center a mobile unit instead of a building, a training trailer was designed and purchased instead of constructing the planned Training Center facility. This decision proved to be the correct one since the training trailer is now being heavily used throughout Northern California. The legal and construction management funds were used to support and equip the mobile training unit.

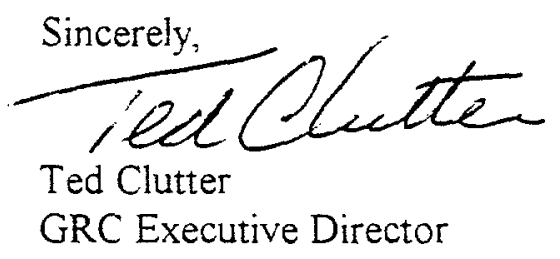




\section{Statement of Work Geothermal Resources Council}

1. SCOPE AND OBJECTIVES

The objective of tiis grant is to provide financial assiscance to enable the GRC to provide a service to the Geothermal Industry.

\section{BACKGROUND}

The Geothermal Resources Courcil is a non-profit organization. The GRC represents the geothermal community through membership in its organization.

\section{TASRS}

The following tasks are considered to be representative of the work that will be done through this grant. Many of the lasks are ongoing or level of effort and do not necessarily have a milestone completion date.

3.11994 Annual Conference: In October of 1994 the GRC will hold its annual conference in Salt take City. The GRC vill organize the conference, including soliciting for papers to be presented, short courses to be given, tours of geothermal poter plants and resources and the exhibits in an exhibit hall.

3.2 Geothemal Well Control Driling Course: Update those who attended the well control course in 1992 on actual operations of well control and to jupart knowledge on any new well control rechnology that bas been developed in the interim.

3.3. Expand the GRC Online Iibrary: Incorporate new citations inco the database and add keywords to the citations. Provide raintenance and minor programing to the on-line computer and loacing of new dacabases.

3.4 Geothermal Poster: In collaboration with the Geothermal Education office, derelop and print a poster on geotherwal development.

3.51995 Forld Geothermal Congress: Provide representarion at the 1995 World Geothermal Congress to further the export program.

3.6 Geothermal Heat Pump Iraining Center: Provide for the planning, architectural design, legal fees, construction management and sales of use-days of the Geothermal Heat Pump Training Center.

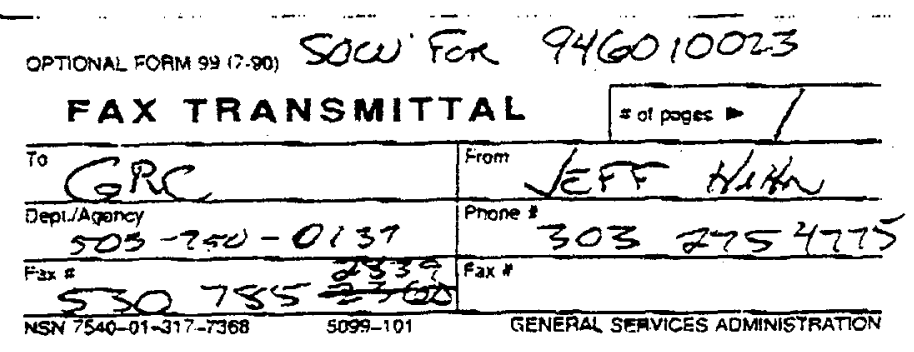

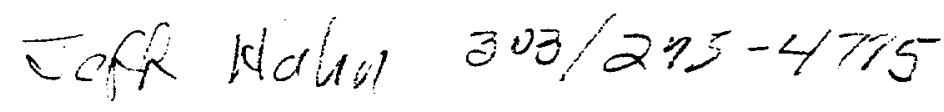

